Sandra Rey *

\title{
0 prazer da imagem
}

Sandra Rey é Artista pesquisadora e professora. Dra. em Arte e Ciências da Arte pela Universidade de Paris I. Seu projeto artístico fundamenta-se, tanto prática quanto teoricamente, em interrogações sobre a estabilidade e instabilidade da imagem fotográfica em relação ao real, com base em caminhadas na natureza. Expõe e publica textos de artista e crítica de arte. Produz obras em grandes e pequenos formatos, vídeos, instalações e livros de artista. Pesquisadora no $\mathrm{CNPq}$ (PQ-IC) e docente no PPG Artes Visuais da UFRGS. <sandrarey@gmail.com > ORCID: 0000-0003-4907-9373
Resumo $O$ ensaio aborda a noção de experiência estética estabelecendo relações com o ato de caminhar no contexto de um projeto que delineia um processo artístico individual. A expansão da experiência através da dimensão estética é o que torna possível perceber o mundo de outra maneira seja na vida, seja na arte.

Palavras chave Experiência estética, Caminhada, Paisagem.

\section{The pleasure of the image}

Abstract The text aims to present the notion of aesthetic experience establishing relationships with the act of walking in the context of a project that outlines an individual artistic process. The expansion of experience through the aesthetic dimension is what makes it possible to perceive the world in another way, whether in life or in art.

Keywords Experience, Hiking, Landscape. 


\title{
A ampliação da experiência
}

\author{
Como é possível descrever o prazer da imagem? \\ Como teorizar essa sensação?
}

Talvez fosse melhor abordar o prazer da imagem através daquilo que lhe deu origem, isto é, como uma experiência expandida pelo adjetivo estético, e perguntar:

- Quando, uma experiência, adquire qualidades estéticas? Sob que condições isso ocorre?

O "estético", para Jauss ${ }^{1}$ é um termo que reúne, numa síntese complexa, um esforço de inteligibilidade da experiência sensorial e um exercício discursivo que, tendo as suas próprias regras, é independente do domínio perceptivo, e se desenvolve através de uma reconstrução imaginária deste.

A experiência estética ocorre, é Jauss quem afirma, quando a consciência se desprende da coação dos costumes, e dos interesses, liberando o indivíduo do fazer cotidiano, possibilitando outras vivências que tornam possível perceber o mundo de outra maneira.

Eis meu projeto: partir da experiência para construir um objeto que se quer artístico.

Qual experiência? A experiência de caminhar e fotografar (duas coisas que sempre gostei de fazer; muito antes de incorporar o deslocamento e a caminhada no meu projeto artístico).

Lembro estar no alto de uma falésia, olhando para o mar. Após uma subida íngreme eis que o chão desaparece por um corte radical da paisagem e, diante do vazio, surge o mar. Precisei dar um tempo para respirar e olhar. Foi quando a ideia me veio à mente.

- Por que não, pensei, fazer arte com o que gosto de fazer?

Fazer da arte uma prática daquilo que se gosta fazer. Essa a proposta.

Sempre gostei de caminhar sozinha, ou em pequenos grupos, com amigos. O procedimento é muito simples, sapatos confortáveis, carregar o mínimo possível e, tendo determinado um ponto de partida, seguir adiante sem trajeto estabelecido, simplesmente ir.

Para onde? Sei lá, para onde meus passos me levarem.

Andar e observar o mundo à minha volta. Esse é um exercício que me situa no agora.

Era o mês de agosto, verão em 2003, na França, tinha recém adquirido minha primeira câmera reflex digital, e me sentia como uma criança com brinquedo novo, encantada pela possibilidade de escrutar a natureza nas suas diferentes nuances, pelo enquadramento da câmera fotográfica, e transformar na imagem, o território em paisagem. 


\section{Um projeto e suas articulações}

Desdobramentos da Paisagem, é o projeto que venho desenvolvendo e este organiza-se através de três eixos principais:

- a caminhada como experiência estética,

- os arquivos de deslocamentos que são um banco de imagens, work in progress, onde armazeno as fotografias obtidas durante as experiências na natureza, e ...

- uma prática artística em estúdio e ateliê com base em processos de montagem das fotografias arquivadas.

Na vida cotidiana, caminhar é mera questão prática, um meio de locomoção automático entre dois lugares.

Mas fazer da caminhada uma investigação, uma meditação ou até um ritual, depende da maneira como investimos certos atos de significações particulares.

As fotografias que resultam das minhas caminhadas reforçam a convicção de não-pertencimento, da diferença fundamental que separa o humano, da natureza. É somente pela imagem que a relação se faz, relação essa que adquire a forma de uma imagem-paisagem.

Gosto de viajar para longe para caminhar. Então, sempre que posso, viajo para realizar meu projeto: caminhar e fotografar.

A viagem possibilita deslocar de um lugar a outro, permite-me alcançar lugares distantes em curto espaço de tempo. Já o caminhar me coloca em movimento na medida exata, e nos limites, do meu corpo. Também contém algo de simbólico: à medida em que avanço, deixo algo para atrás.

É o movimento de atravessar a paisagem que faz as coisas acontecerem na mente e é isso que torna ambígua e fértil essa experiência que é, ao mesmo tempo, meio e fim, trajeto e destino.

Em A história do caminhar ${ }^{2}$, Rebbeca Solnit afirma que o caminhar evoca um estado no qual a mente, o corpo e o mundo, se alinham. 0 ritmo da caminhada, diz ela, produz uma espécie de raciocínio ritmado pelo trocar dos passos, e a travessia de uma paisagem ecoa e estimula a travessia de uma série de pensamentos, o que produz uma estranha harmonia entre travessias internas e externas, sugerindo que a mente é uma espécie de paisagem e que caminhar é uma maneira de percorrê-la.

$\mathrm{Na}$ arte, a experiência estética é, antes de tudo, uma experiência da incerta transição que atravessa qualquer divisão que queiramos estabelecer entre arte e não-arte.

- Quando estou no campo da arte, quando me encontro fora dele, quando caminho na natureza? Isso, é algo que não saberia delimitar com precisão... Mas essa zona de indeterminação, justamente, é que me parece produtiva.

No fim das contas, a experiência estética é a própria experiência da inadequação ou da instabilidade de um ato, ou situação, como experiência 
artística. Mesmo quando tentamos descrever como estética a adequação interna dos seus elementos.

Visto em conjunto, todos os aspectos de um sítio se mostram sob o mesmo plano, qualquer que seja a ordem em que se apresentam. $O$ que importa, na realidade, não é o que aparece, mas o que se ativa na mente, no atravessamento do meu olhar e a geografia do lugar.

A fotografia é um rastro, documento, e resíduo que fica como registro das caminhadas.

A liberação que ocorre por meio da caminhada efetua-se em dois planos: num primeiro momento, para a consciência receptiva, como aisthesis: experiência estética que ocorre quando, no atravessamento de um sítio, o território se transforma em paisagem, tornando possível perceber o mundo de maneira diferente.

Num segundo momento como poiésis. Poiésis entendida aqui como capacidade poiética que designa a experiência estética fundamental que ocorre durante o fazer da arte.

No meu processo a poiésis acontece através de processos de montagem justapondo várias fotografias de maneiras a cruzar pontos de vista e produzir certos estranhamentos desestabilizando, e até desidentificando o referente na natureza, em relação à sua imagem icônica.

No meu processo, a montagem é um método e uma estratégia para produzir singularização e estranhamento do objeto, um procedimento que consiste em complexificar a forma para aumentar a dificuldade e a duração da percepção.

A arte, para mim, é sempre caminho da experiência artística, meio de sentir o devir do objeto.

Chklovski ${ }^{3}$ diz que "a finalidade da arte é transmitir uma sensação do objeto como uma visão, e não como uma identificação de algo conhecido. Isso porque, na arte, o processo perceptivo é um fim em si, por essa razão deve ser prolongado. 0 procedimento da arte é extrair a imagem do automatismo da percepção, afirma.

Pensar a arte como procedimento, não como produto acabado. A arte como procedimento acontece quando torna suscetível reviver a realização do objeto, por meio de uma reconstrução imaginária deste.

$\mathrm{O}$ prazer da imagem seria, então, inversamente proporcional à familiaridade com aquilo que conhecemos do mundo; e ainda de acordo com Chklovski, à arte caberia a apresentação daquilo que conhecemos, de uma nova e estranha forma. Assim, penso eu, a arte está diretamente ligada à desfamiliarização do que é percebido, mesmo que aquilo que vemos, o tenhamos visto por inúmeras vezes. E o que o estranhamento provoca na percepção do sujeito é contaminado pelo prazer suscitado pela apropriação subjetiva do objeto, desencadeando o que podemos denominar como experiência estética. 
1 JAUSS, Hans Robert. A estética da recepção: colocações gerais. In LIMA, Luiz Costa. A Literatura e o leitor: textos de estéticas da recepção. Rio de Janeiro: Paz e Terra, 1979. p. 43 - 61.

2 Solnit, Rebbeca. A história do caminhar. São Paulo: Martins Fontes, 2016.

3 CHKLOVSKI, Victor. L'art comme procedé. Paris: Ed. Allia, 2008.

\section{Referências}

CHKLOVSKI, Victor. L'art comme procedé. Paris: Ed. Allia, 2008.

JAUSS, Hans Robert. A estética da recepção: colocações gerais. In: LIMA, Luiz Costa. A Literatura e o leitor: textos de estéticas da recepção. Rio de Janeiro: Paz e Terra, 1979. p. 43 - 61. Solnit, Rebbeca. A História Do Caminhar. São Paulo: Martins Fontes, 2016. 